\title{
EFEKTIFITAS IMPLEMENTASI UNDANG-UNDANG NOMOR 16 TAHUN 2011 TENTANG BANTUAN HUKUM DI KABUPATEN KOLAKA
}

\author{
La Ode Dedihasriadi \\ Universitas Sembilan Belas November Kolaka \\ Email : id.dedihasriadi@gmail.com
}

\begin{abstract}
Abstrak
Pasal 28D Undang - Undang Dasar Tahun 1945 juga menyebutkan bahwa "Setiap orang berhak atas pengakuan, jaminan, perlindungan, dan kepastian hukum yang adil serta perlakuan yang sama di hadapan hukum". Artinya bahwa Negara memastikan setiap individu maupun warga Negara mendapatkan akses jaminan keadilan dan kepastian hukum serta kesamaan kedudukan dalam hukum dengan hadirnya undang-undang nomor 16 tahun 2011 tentang bantuan hukum. Metode penelitian yang di gunakan adalah normatif-empiris lebih detailnya mengkaji penerapan ketentuan hukum normatif (undang-undang) terhadap peristiwa hukum yang terjadi dalam masyarakat. Hasil penelitian mencerminkan bahwa implementasi keberadaan Undang - Undang Nomor 16 Tahun 2011 tentang Bantuan Hukum di kabupaten kolaka telah terlaksana dengan baik dan tepat sasaran sesuai dengan cita-cita dan harapan yang telah di amanatkan oleh konstitusi. Hal ini di karenakan semua stakeholder yang berada di kabupaten kolaka memiliki kesadaran kolektif tentang penting akses keadilan public untuk semua warga negara tanpa terkecuali.
\end{abstract}

Kata kunci: Efektifitas, Bantuan Hukum, Keadilan

\section{Abstract}

Article 28D The 1945 Constitution also states that "Every person shall have the right of recognition, guarantees, protection and certainty before a just law, and of equal treatment before the law". This means that the State ensures that every individual and citizen has access to the guarantee of justice and legal certainty as well as the equality of position in the law with the advent of Law Number 16 of 2011 concerning legal aid. The research used normative and empirical legal research method specifically examining the application of normative legal provisions (laws) to legal events that occur in society. The results of the study showed that the implementation of the Act No. 16 of 2011 concerning legal assistance in Kolaka Regency has been well implemented and achieved the target which was mandated by the constitution. This was due to the fact that all 
stakeholders in Kolaka Regency have a collective awareness on the importance of access to public justice for all citizens without any exception.

Keywords: Effectiveness, legal aid, justice

\section{A. Pendahuluan}

Eksistensi Indonesia sebagai negara hukum tertuang dalam Pasal 1 Ayat (3) UUD NRI Tahun 1945 menyatakan bahwa Negara Indonesia adalah negara hukum. Sebagai negara hukum (rechtaat), Indonesia dalam menjalankan roda pemerintahanya tentunya berdasarkan kaidah-kaidah hukum yang tertuang di dalam undang-undang maupun aturan yang yang tercipta di dalam masyarakat yang telah di akui dan di sepakati. Selain itu, Prinsip utama Sebagai negara hukum adalah mendorong atau mengedapankan perlindungan eksistensi Hak Asasi Manusia (HAM) dalam bernegara. Hal ini sebagaimana yang tertuang dalam Pasal 27 Ayat (1) UUD NRI tahun 1945 "Segala warga negara bersama kedudukannya di dalam hukum dan pemerintahan wajib menjunjung hukum dan pemerintahan itu dengan tidak ada kecualinya". Artinya bahwa negara Indonesia memiliki kewajiban untuk memberikan perlindungan dan pengakuan terhadap hak asasi manusia dari setiap individu maupun warga negaranya. Pada konteks ini, Indonesia sebagai negara hukum memberikan perlindungan dan pengakuan terhadap hak asasi manusia setiap warga negaranya tanpa terkecuali termaksud dalam memberikan bantuan hukum secara Cuma-Cuma kepada setiap warga negaranya yang membutuhkan. Hal ini demi tercapainya prinsip equalty before the law yang merupakan pondasi dari negara hukum.

Konsekuensi dari prinsip equality before the law. ${ }^{1}$ Salah satunya adalah negara berupaya untuk mewujudkan keadilan atau kesamaan kedudukan dalam hukum yaitu dengan hadirnya bantuan hukum bagi setiap warga negara yang terlibat dalam kasus hukum. Menurut Soerjono Soekanto, bantuan hukum pada pokoknya memiliki arti bantuan hukum yang diberikan oleh para ahli bagi warga masyarakat yang memerlukan untuk mewujudkan hak-haknya serta juga mendapatkan perlindungan hukum yang wajar. ${ }^{2}$

${ }^{1}$ Suyogi Imam Fauzi dan Inge Puspita Ningtyas, 2018, Optimalisasi Pemberian Bantuan Hukum Demi Terwujudnya Access to Law and Justice Bagi Rakyat Miskin, Konstitusi, Vol. 15, No. 1, hlm. 52 .

${ }^{2}$ IGN. Ridwan Widyadharma, 2010, Profesional Hukum dalam Pemberian Bantuan Hukum, Badan Penerbit Universitas Diponegoro, Semarang, hlm. 26. 
Selain itu, dalam konstitusi Pasal 28D UUD NRI Tahun 1945 juga menyebutkan bahwa "Setiap orang berhak atas pengakuan, jaminan, perlindungan, dan kepastian hukum yang adil serta perlakuan yang sama di hadapan hukum". Artinya bahwa Negara memastikan setiap individu maupun warga Negara mendapatkan akses kepastian jaminan keadilan dalam menghadapi proses-proses hukum yang dihadapi oleh masyarakat miskin yang bersengketa hukum di hadapan pengadilan.

Tentunya, Indonesia sebagai negara hukum yang mengakui dan melindungi serta menjamin hak asasi warga negara terhadap akses pada keadilan (access to justice) dan kesamaan di hadapan hukum (equality before the law) bertanggung jawab menyelenggarakan pemberian bantuan hukum kepada semua masyarakat. Untuk Jaminan atas hak konstitusional tersebut agar memadai, maka didoronglah lahirnya Undang - Undang Nomor 16 Tahun 2011 tentang Bantuan Hukum yang menjadi dasar bagi negara untuk menjamin warga negara khususnya bagi orang atau kelompok rentan untuk mendapatkan akses pada keadilan. ${ }^{3}$ Keberadaan Undang - Undang Bantuan Hukum (UU No. 16 tahun 2011) tersebut merupakan bentuk komitmen Negara Indonesia dalam menjamin warga negaranya untuk mengakses keadilan tanpa memandang latar belakang agama, ras, etnis, suku, politik, gender dan golongan.

Hadirnya Undang - Undang Bantuan Hukum merupakan instrumen turunan dari Pasal 28D UUD NRI Tahun 1945. Tujuan Bantuan Hukum tertuang dalam untuk Pasal 3 Undang - Undang Nomor 16 Tahun 2011 tentang Bantuan Hukum:

a. Menjamin dan memenuhi hak bagi Penerima Bantuan Hukum untuk mendapatkan akses keadilan;

b. Mewujudkan hak konstitusional segala warga negara sesuai dengan prinsip persamaan kedudukan didalam hukum;

c. Menjamin kepastian penyelenggaraan Bantuan Hukum dilaksanakan secara merata di seluruh wilayah Negara Republik Indonesia; dan

d. Mewujudkan peradilan yang efektif, efisien, dan dapat dipertanggungjawabkan.

Penyelenggaraan pemberian bantuan hukum yang diberikan kepada penerima bantuan hukum merupakan upaya untuk mewujudkan hak-hak konstitusi dan sekaligus sebagai implementasi negara hukum yang mengakui

${ }^{3}$ Fachrizal Afandi, Implementasi Pengabdian Masyarakat Berbasis Access to Justice Pada Lembaga Bantuan Hukum Kampus Negeri Pasca Pemberlakuan Undang - Undang Bantuan Hukum, Jurnal Rechtsvinding, Vol. 2 No. 1, hlm. 32. 
dan melindungi serta menjamin hak warga negara akan kebutuhan akses terhadap keadilandan kesamaan di hadapan hukum. Bantuan hukum pula merupakan pelayanan hukum yang bertujuan untuk memberikan perlindungan hukum dan pembelaan terhadap hak-hak konstitusi tersangka/terdakwa sejak ditahan sampai diperolehnya putusan pengadilan yang tetap. Yang dibela dan diberi perlindungan hukum bukan kesalahan tersangka / terdakwa melainkan hak tersangka / terdakwa agar terhindar dari perlakuan dan tindakan tidak terpuji atau tindakan sewenang-wenang dari aparat penegak hukum. Jadi meskipun tersangka / terdakwah memang terbukti bersalah, mereka tetap memiliki hak untuk mendapatkan bantuan hukum. ${ }^{4}$

Dalam Pasal 4 Ayat (1) Undang - Undang Bantuan Hukum juga menyebutkan bahwa ruang lingkup penerima bantuan hukum adalah orang yang menghadapi masalah hukum baik masalah hukum keperdataan, pidana, dan tata usaha Negara baik litigasi maupun non litigasi. Lebih lanjut undang undang tersebut juga menyebutkan bahwa penerima bantuan hukum meliputi setiap orang atau kelompok orang miskin yang tidak dapat memenuhi hak dasar secara layak dan mandiri. Hak dasar tersebut meliputi hak atas pangan, sandang layanan kesehatan, layanan pendidikan, pekerjaan dan berusaha, dan/atau perumahan.

Sehubungan dengan lahirnya Undang - Undang Nomor 16 Tahun 2011 tentang Bantuan Hukum sebagai media untuk menjamin akses keadilan hukum kepada masyarakat miskin, maka bagaimakah implementasi undang-undang tersebut di kabupaten kolaka, Sulawesi tenggara terhadap warga Negara yang tidak mampu secara ekonomi dalam mengakses keadilan (access to justice) jika berhadapan dengan permasalahan hukum demi tercapainya prinsip Negara Indonesia sebagai Negara hukum yaitu (equality before the law).

Oleh karena itu, berdasarkan harapan konstitusi dalam menjamin hak asasi manusia dalam mencapai keadilan dalam penegakan hukum terhadap semua warga negaranya, maka penulis tertarik mengangkat kajian tentang Bagaimana efektifitas implementasi Undang - Undang Nomor 16 Tahun 2011 tentang Bantuan Hukum di Kabupaten Kolaka?

${ }^{4}$ Angga, Ridwan, Arifin, 2018, Penerapan Bantuan Hukum Bagi Masyarakat Kurang Mampu di Indonesia, Diversi Jurnal Hukum, Vol. 4, No. 2, hlm. 226. 


\section{B. Metode Penelitian}

Dalam penelitian ini, menggunakan Metode penelitian hukum normatif empiris. Dimana metode penelitian yang menggunakan penggabungan antara pendekatan hukum normatif dalam kacamata empiris. Metode penelitian normatif-empiris lebih detailnya mengkaji penerapan ketentuan hukum normatif (undang-undang) terhadap peristiwa hukum yang terjadi dalam masyarakat.

\section{Hasil dan Pembahasan}

\section{Eksistensi Lahirnya Undang - Undang Nomor 16 Tahun 2011}

Indonesia merupakan negara yang menganut sistem negara hukum (rule of law). Negara hukum di sini mengisyaratkan bahwa dimana kedudukan seluruh warganya sama di depan hukum tanpa terkecuali. Selain menganut sistem rule of law, Indonesia juga merupakan negara yang berdasar hukum (recht staat). Dasar pijakan bahwa negara Indonesia adalah negara hukum tertuang dalam Undang-undang Dasar 1945, ketentuan ini menunjukkan semakin kuatnya dasar hukum serta menjadi amanat negara, bahwa negara Indonesia adalah dan harus merupakan negara hukum yang berarti bahwa segala bentuk persoalan yang menyangkut urusan antara warga negara dengan warga negara atau warga negara dengan negara (pemerintah), harus didasarkan pada hukum dan peraturan perundang-undangan yang berlaku di Indonesia. Sebagai konsekuensinya, maka setiap warga negara juga berhak mendapatkan perlindungan hukum yang sama tanpa terkecuali. ${ }^{5}$

Terdapat dua istilah terkait dengan bantuan hukum yaitu legal aid dan legal assistance. Istilah legal aid biasanya dipergunakan untuk menunjukkan pengertian bantuan hukum dalam arti sempit, yaitu pemberian jasa-jasa di bidang hukum kepada seseorang yang terlibat dalam suatu perkara secara cuma-cuma khususnya bagi mereka yang tidak mampu. Sedangkan pengertian legal assistance dipergunakan untuk menunjukkan pengertian bantuan hukum dalam arti luas, karena di samping bantuan hukum terhadap mereka yang tidak mampu, juga pemberian bantuan hukum yang dilakukan oleh para pengacara yang

${ }^{5}$ Mustika Prabaningrum Kusumawati, 2016, Peranan Dan Kedudukan Lembaga Bantuan Hukum Sebagai Access To Justice Bagi Orang Miskin, Arena Hukum, Vol. 9, No. 2, hlm. 191. 
mempergunakan honorarium atau mendapatkan pembayaran sejumlah uang dari klien. ${ }^{6}$

Pada ketentuan Bab 1, Pasal 1 Angka 1, Undang-Undang Nomor 16 Tahun 2011 tentang Bantuan Hukum, menyebutkan: "Bantuan Hukum adalah jasa hukum yang diberikan oleh Pemberi Bantuan Hukum secara cuma-cuma kepada Penerima Bantuan Hukum". Sedangkan penerima bantuan hukum di sini adalah orang atau kelompok orang miskin. dan Pemberi Bantuan Hukum adalah Lembaga Bantuan Hukum atau organisasi kemasyarakatan yang memberi layanan bantuan hukum seperti yang dijelaskan dalam Undang -Undang Nomor 16 Tahun 2011 tentang Bantuan Hukum. $^{7}$

Pasal 9 menjelaskan bahwa pemberi bantuan hukum itu berhak:

a. melakukan rekrutmen terhadap advokat, paralegal, dosen, dan mahasiswa fakultas hukum;

b. melakukan pelayanan Bantuan Hukum;

c. menyelenggarakan penyuluhan hukum, konsultasi hukum, dan program kegiatan lain yang berkaitan dengan penyelenggaraan Bantuan Hukum;

d. menerima anggaran dari negara untuk melaksanakan Bantuan Hukum berdasarkan Undang-Undang ini;

e. mengeluarkan pendapat atau pernyataan dalam membela perkara yang menjadi tanggung jawabnya di dalam sidang pengadilan sesuai dengan ketentuan peraturan perundang-undangan;

f. mendapatkan informasi dan data lain dari pemerintah ataupun instansi lain, untuk kepentingan pembelaan perkara; dan\

g. mendapatkan jaminan perlindungan hukum, keamanan, dan keselamatan selama menjalankan pemberian Bantuan Hukum.

Pemberi bantuan hukum juga berkewajiban:

a. melaporkan kepada Menteri tentang program Bantuan Hukum;

b. melaporkan setiap penggunaan anggaran negara yang digunakan untuk pemberian Bantuan Hukum berdasarkan Undang-Undang ini;

${ }^{6}$ Sukinta, 1997, Peranan Lembaga Bantuan Hukum Bagi Masyarakat dalam Memperoleh Keadilan, Fakultas Hukum Universitas Diponegoro, Semarang, hlm. 4.

${ }^{7}$ Herning Setyowati, Nurul Muchiningtias, 2018, Peran Advokat dalam Memberikan Bantuan Hukum kepada Masyarakat dalam Perspektif Hak Asasi Manusia, Lex Scientia Law Review, Vol. 2 No. 2, hlm. 156. 
c. menyelenggarakan pendidikan dan pelatihan Bantuan Hukum bagi advokat, paralegal, dosen, mahasiswa fakultas hukum yang direkrut sebagaimana dimaksud dalam Pasal 9 huruf a;

d. menjaga kerahasiaan data, informasi, dan/atau keterangan yang diperoleh dari Penerima Bantuan Hukum berkaitan dengan perkara yang sedang ditangani, kecuali ditentukan lain oleh undang-undang; dan

e. memberikan Bantuan Hukum kepada Penerima Bantuan Hukum berdasarkan syarat dan tata cara yang ditentukan dalam UndangUndang ini sampai perkaranya selesai, kecuali ada alasan yang sah secara hukum.

Dengan adanya bantuan hukum yang diberikan oleh negara melalui Kementerian Hukum dan Hak Asasi Manusia Republik Indonesia diharapkan semua lapisan masyarakat yang kurang mampu untuk mencari keadilan dan kesetaraan di muka hukum dapat terpenuhi hak-haknya sebagaimana diamanatkan dalam pasal 28D UUD NRI Tahun $1945 .{ }^{8}$ Akses terhadap keadilan didefinisikan sebagai kemampuan masyarakat untuk mencari dan memperoleh obat melalui lembaga formal atau informal keadilan bagi keluhan sesuai dengan standar hak asasi manusia. ${ }^{9}$

Hal ini merupakan akses bagi masyarakat, khususnya kelompok miskin terhadap mekanisme yang adil, efektif dan akuntabel untuk melindungi hak, menghindari penyalahgunaan adalah kemampuan masyarakat untuk memperoleh dan mendapatkan penyelesaian melalui mekanisme formal dan informal dalam sistem hukum, serta kemampuan untuk memperoleh dan terlibat dalam proses pembuatan dan penerapan dan pelembagaan hukum. ${ }^{10}$ Undang-undang ini juga menyampaikan bahwa Dalam Pemberian Bantuan hukum untuk masyarakat miskin memiliki hak dan kewajiban di antaranya:

Penerima Bantuan Hukum berhak:

a. mendapatkan Bantuan Hukum hingga masalah hukumnya selesai dan/atau perkaranya telah mempunyai kekuatan hukum tetap, selama

${ }^{8}$ Angga, Ridwan, Arifin, op.cit, hlm. 228.

${ }^{9}$ United Nations Development Programme, UNDP, 2005, "Programming for Justice: Access for All: A Practitioner's Guide to a Human Rights-Based Approach to Access to Justice”, Thailand, hlm. 3. Dalam, Suyogi Imam Fauzi dan Inge Puspita Ningtyas, op.cit, hlm. 57.

${ }^{10}$ Supra, Kerangka Kerja untuk Penguatan Akses Hukum dan Keadilan di Indonesia, Justice for The Poor Project The World Back, Jakarta, hlm. 2. 
Penerima Bantuan Hukum yang bersangkutan tidak mencabut surat kuasa;

b. mendapatkan Bantuan Hukum sesuai dengan Standar Bantuan Hukum dan/atau Kode Etik Advokat; dan

c. mendapatkan informasi dan dokumen yang berkaitan dengan pelaksanaan pemberian Bantuan Hukum sesuai dengan ketentuan peraturan perundang-undangan.

Penerima Bantuan Hukum wajib:

a. menyampaikan bukti, informasi, dan/atau keterangan perkara secara benar kepada Pemberi Bantuan Hukum;

b. membantu kelancaran pemberian Bantuan Hukum.

Keberadaan UU bantuan hukum merupakan Semangat Negara dalam mewujudkan acces to law and justice kepada masyarakat miskin sebagai wujud dalam menjalankan amanah yang di perintahkan oleh konstitusi. Selain mendorong terciptanya akses keadilan hukum bagi masyarakat miskin, Negara juga berupaya menjadi ladang bagi masyarakat miskin untuk mencapai kesejahteraannya dalam mendapatkan kedudukannya dimata hukum sebagaimana yang tertuang dalam prinsip konstitusi yaitu equality before the law atau setiap orang sama kedudukannya di mata hukum.

2. Efektivitas Implementasi Undang - Undang Nomor 16 Tahun 2011 tentang Bantuan Hukum di Kabupaten Kolaka

Kabupaten Kolaka adalah sebuah kabupaten di provinsi Sulawesi Tenggara, Indonesia. Ibu kotanya adalah Kolaka. Kabupaten Kolaka telah dua kali mengalami pemekaran, yakni Kabupaten Kolaka Utara, dan yang terbaru adalah Kabupaten Kolaka Timur yang telah disahkan pada akhir tahun 2012. Pasca pemekaaran, Kabupaten Kolaka mencakup jazirah daratan dan kepulauan yang memiliki wilayah daratan seluas $\pm 3.283,64$ $\mathrm{Km} 2$, dan wilayah perairan (laut) diperkirakan seluas $\pm 15.000 \mathrm{Km}^{2}$ dan jumlah penduduk 213.064 jiwa (2011). Dari luas wilayah tersebut Kabupaten Kolaka dibagi dalam 12 (dua belas) Kecamatan. ${ }^{11}$

Dalam implementasinya pemberian bantuan hukum terhadap masyarakat miskin dalam mengakses keadilan di kabupaten kolaka sangatlah terbuka dan tepat sasaran. Sebagaimana hal ini ungkapkan oleh

${ }^{11}$ Wikipedia, Kabupaten Kolaka, https://id.wikipedia.org/wiki/Kabupaten_Kolaka, diakses tanggal 19 Januari 2020, pukul 16.40 WITA. 
ketua LBH Asoka keadilan Sultra bahwa seyogyanya kehadiran UU bantuan hukum khususnya di kabupaten kolaka sangat membantu masyarakat dalam mendapatkan akses keadilan, selain itu masyarakat juga sudah menaruh harapan terhadap penegakan hukum jika mereka bersentuhan dengan pengadilan karena ada jaminan bahwa dalam proses penyelesaian hukum telah di dampingi oleh para pemberi bantuan hukum yang membantu mereka sejak proses pemerikasaan sampai lahirnya putusan pengadilan".

Lebih lanjut Ahmad Jumades ${ }^{12}$ mengatakan bahwa dengan adanya bantuan hukum ini, masyarakat miskin ketika bersentuhan dengan permasalahan hukum tidak lagi apatis terhadap penegakan hukum artinya bahwa selama ini masyarakat miskin berasumsi bahwa ketika mereka bersentuhan hukum akan sulit mendapatkan keadilan karena ketidak mampuan secara ekonomi artinya bahwa ketika berurusan dengan hukum harus berbayar dan mengeluarkan uang yang banyak.

Pada kesempatan lain, Gunawan Wibisono ${ }^{13}$, juga menyampaikan bahwa keberadaan UU bantuan hukum di kabupaten kolaka sudah sangat familiar di kalangan masyarakat miskin. Hal ini di karenakan dalam kurung waktu 3 (tiga) tahun terakhir LBH-LBH yang berada di kabupaten Kolaka rutin memberikan sosialisasi baik secara skala tingkat kabupaten maupun tingkat kecematan kepada semua kepala desa maupun perangkatnya tentang keberdaan UU bantuan hukum ini. Selain memberikan sosialisasi, Lembaga bantuan Hukum tersebut juga memberikan pelatihan keparalegalan kepada perwakilan-perwakilan aparat pemerintah desa sekabupaten kolaka dengan harapan dapat membantu memberikan akses informasi dan teknik penyelesai sengketa hukum pada tingkat aturan yang di perintahkan oleh UU tersebut kepada masyarakat desa masing-masing.

Bahkan untuk LBH "Kolaka 03" telah melakukan pelatihan hukum teknik beracara kepada semua perangkat desa akhir tahun lalu (2019) dan merekrut1 (satu) perangkat desa untuk menjadi paralegal di setiap desadesa yang ada dikabupaten kolaka. Tujuan ini dengan harapan dapat mewujudkan keinginan konstitusi terhadap warga negaranya yang tidak mampu secara ekonomi dalam mengakses keadilan tanpa terkecuali.

\footnotetext{
${ }^{12}$ Wawancara terhadap Ketua LBH Asoka Keadilan Kabupaten Kolaka.

${ }^{13}$ Wawancara terhadap Ketua LBH “Kolaka 03” Kabupaten Kolaka Sulawesi Tenggara.
} 
Pentingnya keberadaan UU bantuan hukum ini, pemerintah daerah kabupaten kolaka melelui Dinas Pemberdayaan Masyarakat Desa (DPMD) selalu menghimbau pemerintah desa untuk selalu menganggarkan dana dalam APBdes untuk pelatihan bantuan hukum sehingga keberadaan UU bantuan hukum ini benar-benar terjamah di masyarakat miskin demi mewujudkan prinsip konstitusi bahwa setiap orang sama kedudukan di mata hukum.

Keberadaan UU bantuan hukum ini sangat membantu mereka dalam menghadapi dan menyelesaikan masalah warga desanya di tataran pemerintah desa. Hal ini di ungkapkan oleh yusran ${ }^{14}$ bahwa dengan hadirnya UU bantuan hukum ini sangat membantu kami dalam mendorong kesadaran masyarakat miskin tentang pentingnya proses penyelesaian hukum berbasis pengadilan jika sengketa tersebut tidak mendapatkan titik temu penyelesaian di pemerintahan desa. Pemerintah desa dengan gambling menjembatani masyarakatnya untuk mendapatkan keadilan lewat pendampingan hukum oleh lembaga bantuan hukum (LBH) yang telah terdaftar tanpa di bayar sepersen pun.

Implementasi UU Bantuan Hukum ini, juga bisa di ukur keberdaannya di pengadilan Negeri Kolaka, menurut achmad ukuyat ${ }^{15}$ bahwa hampir setiap hari proses penyelesaian sengketa hukum yang berada di pengadilan negeri kolaka pasti ada 1 kasus yang dalam proses persidangannya pendampingan hukumnya menggunakan UU bantuan hukum. Ini berarti bahwa peran negara dalam menjamin warga negaranya mengakses pemerataan keadilan telah terwujudkan.

Berdasarkan hasil tela'ah empiris dari berbagai sector dan lembagalembaga dearah/negara yang ada di kabupaten kolaka menandakan bahwa keberadaan UU bantuan hukum dalam tataran implementasi telah berjalan dengan baik dan tepat sasaran sesuai dengan cita dan harapan yang di amanatkan oleh konstitusi. Tercapainya akses kedilan public terhadap masyarakat miskin di seluruh pelosok masyarakat desa yang ada di Kabupaten Kolaka adalah bentuk dari efektifnya kehadiran UU bantuan hukum ini. Terwujudnya Efektifatas ini adalah buah dari kinarja dari seluruh stakeholder yang telah di amanatkan dalam UU Bantuan Hukum sehingga terlaksana sebagaimana yang telah di inginkan oleh konstitusi.

\footnotetext{
${ }^{14}$ Wawancara terhadap Kepala Desa Popalia, Kabupaten Kolaka.

${ }^{15}$ Wawancara terhadap Wakil Ketua Pengadilan Negeri Kolaka.
} 


\section{Kesimpulan}

Keberadaan UU bantuan hukum adalah untuk mendorong masyarakat miskin agar dapat mengakses hukum dan keadilan (acces to law and justice) sebagaimana yang di amanatkan dalam konstitusi UUD NRI Tahun 1945 Pasal 28D juga menyebutkan bahwa "Setiap orang berhak atas pengakuan, jaminan, perlindungan, dan kepastian hukum yang adil serta perlakuan yang sama di hadapan hukum". Artinya bahwa Negara memastikan setiap individu maupun warga Negara mendapatkan akses kepastian jaminan keadilan demi mewujudkan Prinsip equality before the law.

Selain itu, implementasi UU Bantuan Hukum di Kabupaten Kolaka juga telah terlaksana sebagaimana yang menjadi harapan dan cita-cita yang diamanatkan oleh konstitusi. Hal ini adalah akibat dari lahirnya kesadaran kolektif semua stakeholder yang ada di kabupaten kolaka tentang penting pengakuan, jaminan dan perlindungan masyarakat miskin dalam mencari keadilan hukum.

\section{Daftar Pustaka}

\section{Buku}

IGN. Ridwan Widyadharma, 2010, Profesional Hukum Dalam Pemberian Bantuan Hukum, Badan Penerbit Universitas Diponegoro, Semarang.

Sukinta, 1997, Peranan Lembaga Bantuan Hukum Bagi Masyarakat Dalam Memperoleh Keadilan, Fakultas Hukum Universitas Diponegoro, Semarang.

Supra, Kerangka Kerja untuk Penguatan Akses Hukum dan Keadilan di Indonesia, Justice for the Poor Project The World Back, Jakarta.

United Nations Development Programme, UNDP, 2005, "Programming for Justice: Access for All: A Practitioner's Guide to a Human Rights-Based Approach to Access to Justice", Thailand.

\section{Jurnal}

Afandi, Fachrizal, 2013, Implementasi Pengabdian Masyarakat Berbasis Access to Justice Pada Lembaga Bantuan Hukum Kampus Negeri Pasca Pemberlakuan Undang - Undang Bantuan Hukum, Jurnal Rechtsvinding, Vol. 2 No. 1.

Angga, Ridwan, Arifin, 2018, Penerapan Bantuan Hukum Bagi Masyarakat Kurang Mampu di Indonesia, Diversi Jurnal Hukum, Vol. 4, No. 2. 
Fauzi, Suyogi Imam dan Inge Puspita Ningtyas, 2018, Optimalisasi Pemberian Bantuan Hukum Demi Terwujudnya Access to Law and Justice Bagi Rakyat Miskin, Konstitusi, Vol. 15, No. 1.

Kusumawati, Mustika Prabaningrum, 2016, Peranan dan Kedudukan Lembaga Bantuan Hukum Sebagai Access to Justice Bagi Orang Miskin, Arena Hukum, Vol. 9, No. 2.

Setyowati, Herning dan Nurul Muchiningtias, 2018, Peran Advokat Dalam Memberikan Bantuan Hukum Kepada Masyarakat Dalam Perspektif Hak Asasi Manusia, Lex Scientia Law Review, Vol. 2 No. 2.

\section{Peraturan Perundang - Undangan}

Undang - Undang Dasar Negara Republik Indonesia Tahun 1945.

Undang - Undang Nomor 16 Tahun 2011 tentang Bantuan Hukum

\section{Website Internet}

Wikipedia, Kabupaten Kolaka, https://id.wikipedia.org/wiki/Kabupaten_Kolaka, diakses tanggal 19 Januari 2020, pukul 16.40 WITA. 